\title{
Simulation tests of dynamics of vibroisolated railway lines with wibroisolating system based on elastomer elements
}

\author{
JEL: L92 DOI: 10.24136/atest.2019.026 \\ Data zgłoszenia: 15.12.2018 Data akceptacji: 08.02.2019
}

The problem of propagation of vibration waves caused by the movement of rail vehicles in the ground is extremely important from the point of view of environmental protection against negative effects of dynamic impacts caused by rail transport. Therefore, there is a need to develop new methods for analyzing dynamic phenomena related to rail vehicle traffic. One of the methods that can be used to evaluate dynamic interactions is modeling using finite elements. The article presents a dynamic analysis of the track structure model and the impact of the application of its vibroisolation system on the level of ground vibration amplitude associated with the propagation of vibration waves from the track. The application of the finite element method allows for the analysis of the behavior of engineering structures in variable operating conditions dependent primarily on the speed of movement of vehicles on the track. Such analysis includes the use of a number of physical values that can be used to assess the impact of vibration on any engineering object. These values include, above all, acceleration at any measuring point on the measurement cross-section from the track to the engineering construction, e.g. a residential or industrial building as well as displacement or stress, which are dependent on the speed of the rail vehicle. Comparison of these values with generally available criteria and standards allows at the stage of designing the engineering structure for appropriate modifications to the substructure construction to limit the amplitude of the vibrations transmitted to the environment. These modifications consist mainly of the use of an appropriate vibroisolation system in the form of, for example, slabs or mats laid in the rail layer or pads underneath. Correct execution of the simulation requires careful preparation of the numerical model as well as a series of input data. The input data relate mainly to accurate material data concerning both engineering structures (bridges, viaducts, tunnels), rolling stock and soil parameters. Such data allow to prepare a spectrum of forces loading the modelled section of the track. This approach to the design process is particularly important due to the inability to modify the track after built it.

Keywords: simulation tests, vibroisolation, vibration analysis

\section{Introduction}

The article presents an analysis of a subgrade dynamic model of using the of a example tunnel, taking into account the impact of used insulation materials, in the form of mats on the level of vibration acceleration on the ground surface, and a verification of results for their conformity with PN-B-02170:2016-12 standard [5], based on an analysis in a time domain. The problem of spreading vibration waves in the ground, coming from the impact of dynamic actions, enforced mainly by rail transport, is theoretically extremely complicated. The cause of this condition is non-uniformity of the ground, its history, and hydrological and atmospheric conditions. Ground, which is a natural background of all engineering structures is the only elastic and attenuating element for those structures, causing waves coming from one of engineering structures, which is the subgrade with a rail vehicle, to be important for that structure, but also for structures being at a (quite) a large distance. The second important feature of the ground is its deformation mechanism. This is due to the fact that the duration of dynamic actions of engineering structures that cause vibration waves is much shorter than the possible time of the formation of permanent deformations in the ground, which means that elastic and attenuating characteristics of the ground, changing in time, will have a significant impact on the vibration wave spreading in it. The ground, as a solid body, differs fundamentally from the concept of solids in terms of mechanics. It is a fragmented body, consisting of relatively small particles bound with one another, between which there are spaces filled with air, water, or partly with air or water. This results in the ground having generally no ability to retain shape to the same degree as solids considered in mechanics. As mentioned above, the basic feature of the ground is its fragmentation, but what follows is its porosity (identical grains forms at equal sizes can occupy different volumes), whose measure is density, moisture and macro-porosity. Another element that has a significant impact on the propagation of vibration waves in the ground are its strength characteristics, such as compressibility, friction between soil particles, modules of elasticity, Poisson ratio. These, and other features not listed here cause models of wave propagation in the ground to be very complex, and require multiple data received in experimental tests, and compiled statistically. They require the creation of databases for both vibration parameters in various types of ground of, and databases with engineering structures that enforce its vibrations, as well as structures on which vibration waves act. Propagation of vibration is described in theory by Rayleigh surface waves, or when an elastic layer rests on a more rigid substrate, through Love's waves. Theoretically, surface waves constitute certain special integrals of periodic solutions of the two-wave equation, which satisfies specified boundary conditions, i.e. free edge of elastic half space. Hence, these solutions are characterized by wave speed along the half space surface, and what is their most important feature - by fast decay of amplitude as the distance form the surface, and depth grows. This decay is not the result of attenuation, it may be, but it is primarily a specific mutual effect of longitudinal, and transverse waves. Such approach to the assessment of the vibration propagation in the ground, and its impact on engineering structures is not very effective, and therefore forecast methods were developed for vibration propagation in the ground; however, the results obtained are not satisfactory, and are far from reality. This why the vibration wave propagation phenomenon requires the creation of analytical and numerical models for vibration waves in homogeneous and layered ground including interference, internal friction, sealing, compaction, and loosening of soil on the basis of created databases. The developed model was subjected to experimental verification, and then, a vibration wave propagation algorithm was developed, coming from the subgrade, and methods to estimate its effects, with the possibility to forecast and predict the method of active or passive protection for the existing and newly designed engineering structures. 
The said model was prepared using software designed for finite element calculations [4]. The application of the finite element method allows an analysis of behaviour of buildings during the passage of trains. This analysis includes the determination of a number of physical values that can be used to evaluate the impact of vibrations at the any engineering structure. These values will, first of all, comprise acceleration at any measurement point along the measuring section from the track to an engineering structure, e.g. a residential or industrial building, as well as displacement or stress, which are dependent on the speed of a rail vehicle. Comparison of these values with the publicly available criteria and standards allows, at the design stage of an engineering structure, such as a bridge, tunnel, etc., appropriate modifications to the subgrade design, in order to reduce the value of vibration transmitted to the environment $[1,8]$. These modifications consist mainly of a suitable vibroisolation $[2,7,9]$ in the form of e.g. for boards or mats laid in the rail/tramway layer, or pads under the tracks. The correct execution of the simulation requires a careful preparation of the numerical model and a series of input data. Input data are mainly accurate material parameters, relating both to engineering structures (bridges, viaducts, tunnels) and the ground $[3,6]$. The ground structure, as mentioned earlier, is, as a rule, layered. Each of these layers is characterised by different strength characteristics (excavation, embankment, drift) and different levels of vibration attenuation. Simulation of track vehicle rail passage, including trains requires a thorough understanding of the basic rolling stock parameters, such as the maximum speed, maximum axle load, number of cars, and basic geometric dimensions (car lengths, etc.) to define in detail the moment of a specific wheelset passage over the tracks. Such data will allow the development of a spectre of forces applying a load on the simulated track section. Additionally, it is possible to take into account unevenness of the tracks against other railways, which is causing the largest vibrations caused by a passing train. This approach to the design process is important, due to the lack of additional modification options after the completion of works, as well as of costs and time.

\section{Construction of numerical model \\ 1.1 Numerical model}

The numerical model was created on the basis of the detailed design documentation and geo-technical report. A fragment of the a tunnel was analysed, at a length of ca. 100 running metres. Figure 1 shows the global view of the model and the adopted coordinate system. $X$ axis shows the direction of vehicle movement, $Y$ axis is perpendicular to the movement direction in the horizontal plane, and $Z$ axis defines the vertical direction.

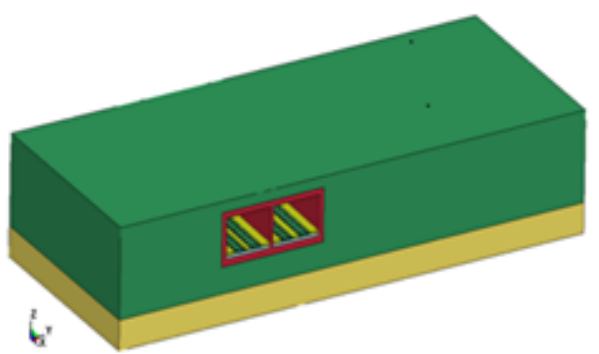

Fig.1. Global view of the model and the definition of the coordinate system
In the tunnel, there was a system of ballast-free rail mounting, RHEDA 2000 type, whose rigidity is $100 \mathrm{kN} / \mathrm{m}$ and the loss ratio, being a measure of ballast attenuation, was assumed to be $\eta=0.3$. View of the finite element grid is shown in figure 2 .

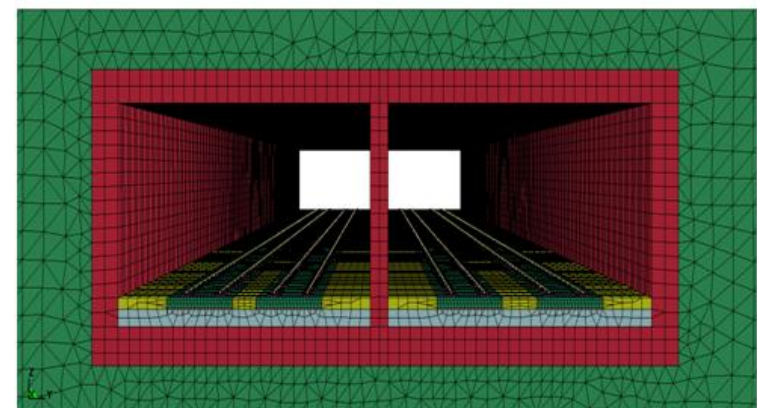

Fig.2. View of the finite element grid

Three models were analysed:

1. Model without an elastic spacer.

2. Model with an insulating mat at a thickness of $\mathrm{g}=50 \mathrm{~mm}$ and volume rigidity parameters $\mathrm{k}_{\mathrm{v}}=0.021 \mathrm{~N} / \mathrm{mm}^{3}$ for $5 \mathrm{~Hz} ; 0.028$ $\mathrm{N} / \mathrm{mm}^{3}$ for $10 \mathrm{~Hz} ; 0.036 \mathrm{~N} / \mathrm{mm}$ for $20 \mathrm{~Hz}$; for calculations, the assumed rigidity was $\mathrm{kv}=0.03 \mathrm{~N} / \mathrm{mm}^{3}$.

3. Model with an insulating mat at a thickness of $\mathrm{g}=30 \mathrm{~mm}$ and volume rigidity parameters $\mathrm{k}_{\mathrm{v}}=0.043 \mathrm{~N} / \mathrm{mm} 3$ for $5 \mathrm{~Hz} ; 0.028$ $\mathrm{N} / \mathrm{mm}^{3}$ for $10 \mathrm{~Hz}$; $0.036 \mathrm{~N} / \mathrm{mm}^{3}$ for $20 \mathrm{~Hz}$; for calculations, the assumed rigidity was $\mathrm{k}_{\mathrm{v}}=0.03 \mathrm{~N} / \mathrm{mm}^{3}$.

Loss factor (attenuation measure) for the mats was assumes to be $\eta=0.05$.

1.2 Boundary conditions and loads for the preset operating conditions

Boundary conditions in the model were chosen in such a way disabling the reflection of propagating waves. It is a common practice in computational geo-mechanics problems; thanks to this approach, the calculation model size can be significantly reduced. The dynamic enforcement was assumed as a simultaneous passage of four trains with the maximum permissible 22.5 t/axle load. Passage speeds were chosen as maximum - respectively, $160 \mathrm{~km} / \mathrm{h}$ for one line, and $100 \mathrm{~km} / \mathrm{h}$ for the second line, as shown in figure 3 .

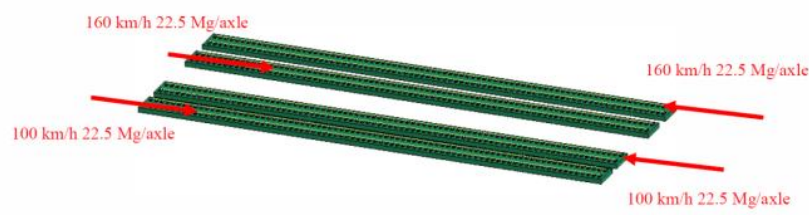

Fig. 3. Dynamic enforcement - passage of trains

Additionally, verification analyses were conducted, in which the enforcement was a Dirac impulse. It was applied to the centre of an extreme high-speed line track. The impulse response allowed an additional assessment, without taking into account the interference of waves propagating from trains travelling in opposite directions. The time distribution of Dirac impulse, and the place of force application are shown below in figure 4 . 

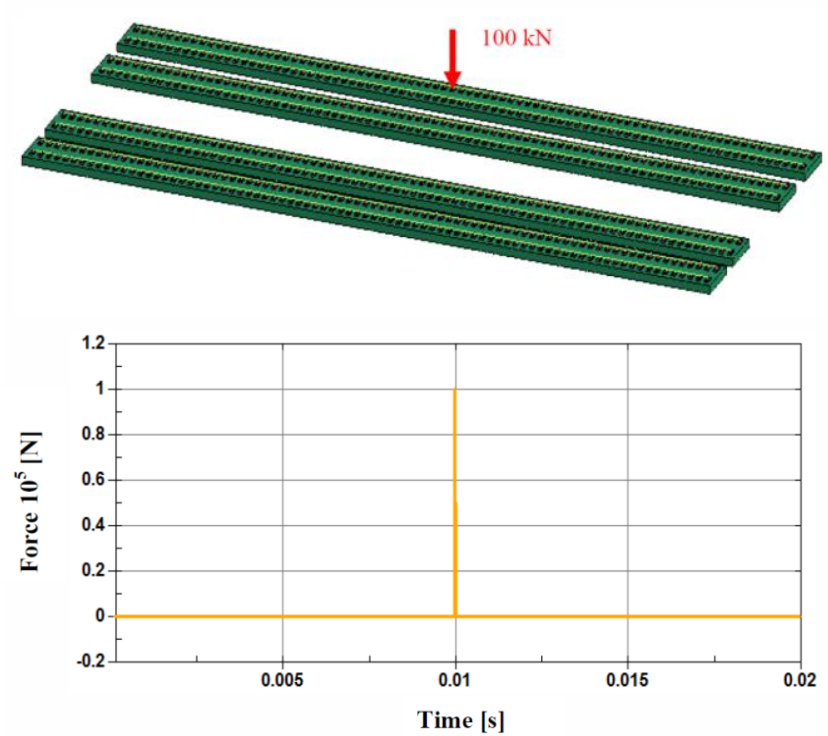

Fig. 4. Dynamic enforcement - Dirac impulse

\section{FEM analyses for model without mats and for model with} insulating mat

2.1 Response to Dirac impulse

Charts presented in Figure 5 contain time responses time to impulse enforcement, applied on the extreme track of a high-speed line.

\section{Without insulating mat}

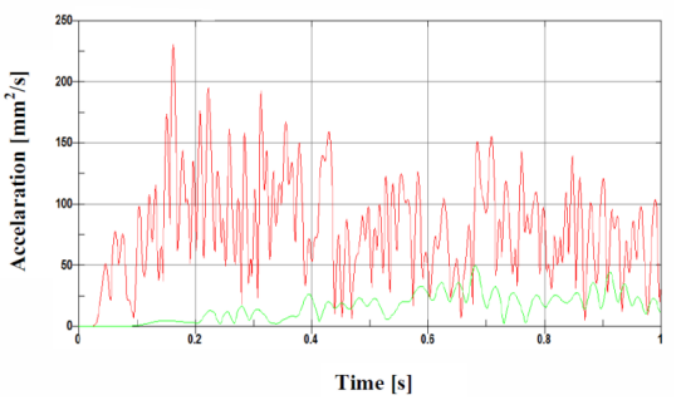

Insulating mat - thickness $\mathrm{g}=50[\mathrm{~mm}]$

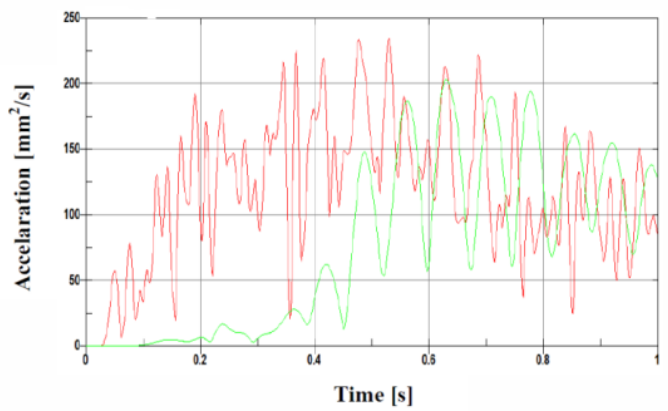

Measurement points

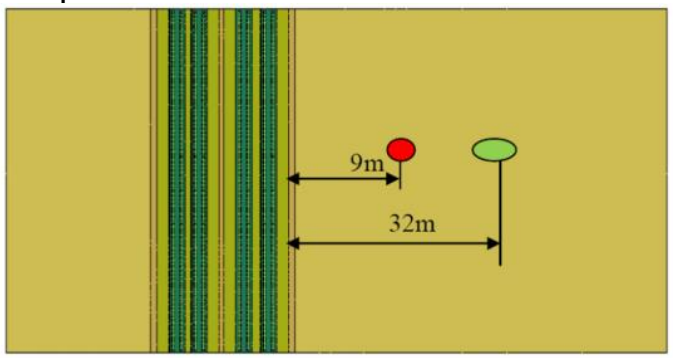

Fig. 5. Impulse responses of with marked measurement points.
Figure 6 shows the distribution of vibration accelerations induced by the passing train, and influence on the environment, by applying an insulating mat at a thickness of $\mathrm{g}=50 \mathrm{~mm}$, after the lapse of $t=0.37 \mathrm{~s}$ and $\mathrm{t}=0.76 \mathrm{~s}$.

\section{$t=0.37 s$}
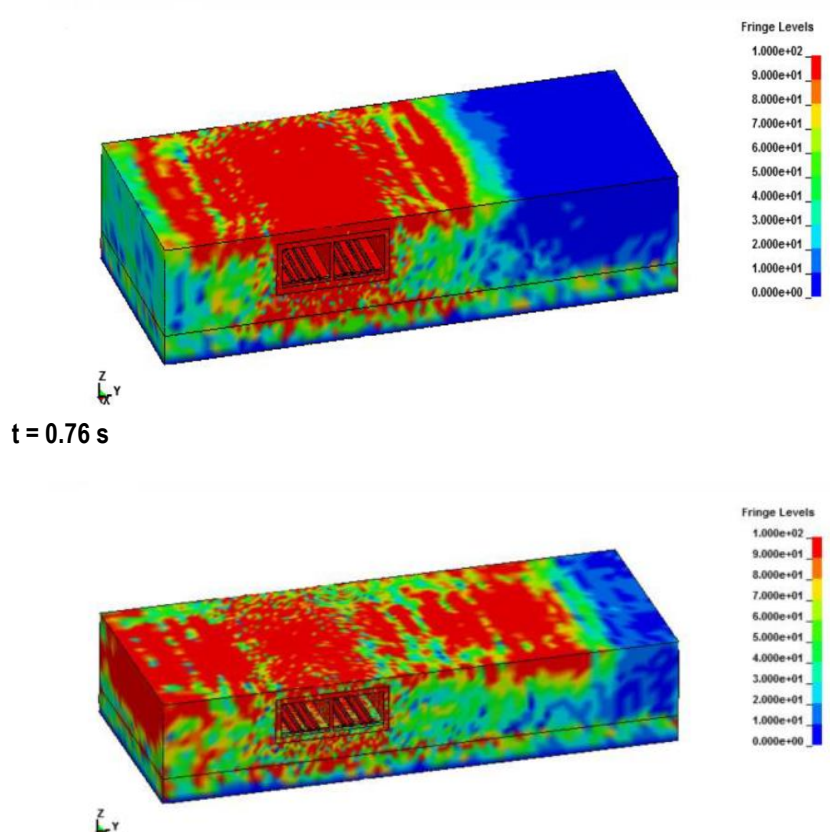

Fig. 6. Distribution of acceleration resultants for impulse responses, for two moments of time

\subsection{Influence oftrain passage on vibration propagation in the ground}

The value of accelerations on the ground surface, depending on the distance from the extreme track, for a model without an insulating mat is shown in figure 7.

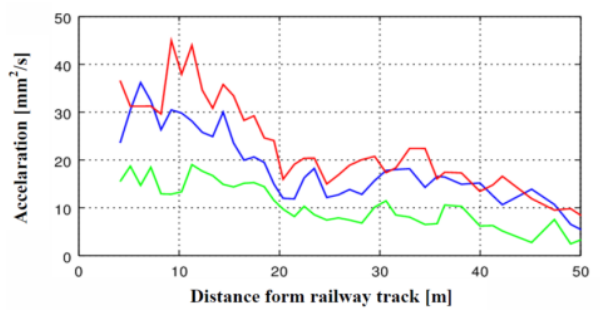

Fig. 7. The value of the accelerations on the ground surface, depending on the distance from the extreme track (--- - direction $X$, --- - direction $Y$, ---- - direction Z)

The value of accelerations on the ground surface, depending on the distance from the extreme track, for a model with an insulating mat at a thickness of $\mathrm{g}=50 \mathrm{~mm}$ is shown in figure 8 .

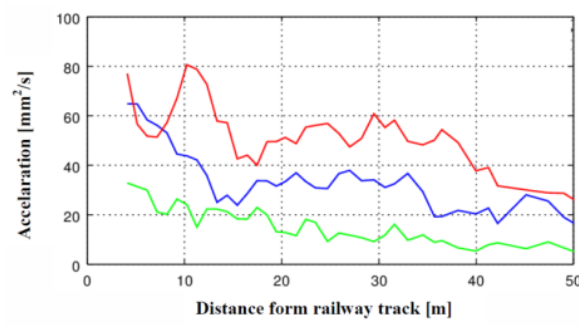

Fig. 8. Acceleration measured on the ground surface, depending on the distance from the extreme track (---- - direction X, ---- - direction $\mathrm{Y}$, ---- - direction Z) 
It can be clearly seen that the amplitude of vibration accelerations in the vertical direction exceeds the amplitude of vibration accelerations in the direction perpendicular to the axis of the track along the entire length of the measured distance, and is followed by an increase when the insulating mat is used.

The value of accelerations on the ground, depending on the distance from the extreme track, for a model with a mat at a thickness of $\mathrm{g}=30 \mathrm{~mm}$, is shown in figure 9 .

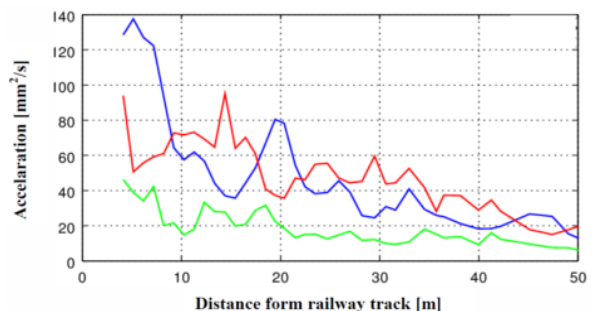

Fig. 9. Acceleration measured on the ground surface, depending on the distance from the extreme track (---- - direction X, ---- - direction $Y$, ---- - direction Z)

For the insulating mat at a thickness of $\mathrm{g}=30 \mathrm{~mm}$, it can be seen that the amplitude of accelerations in the direction longitudinal to the track axis track rapidly increased, which can be associated with the structure of the insulating mat.

As shown in the above considerations, train simulations require a thorough understanding of the basic parameters of rolling stock, such as maximum speed, maximum axle load, number of cars in the rolling stock, and basic geometric dimensions (car base, car length, etc.), enabling a detailed definition of the moment when a specific wheelset travels on the tracks. Such data will allow the development of a spectre of forces applying a load on the simulated track section. Additionally, it is possible to take into account unevenness of the tracks against other railways, which is causing the largest vibrations caused by a passing train. The following illustration (fig. 10) shows a sample configuration of a model for the proposed tunnel, taking into account parameters such as: depth of the tunnel foundation, its geometrical dimensions, building depth under and above the ground, and wall alyout in the building.
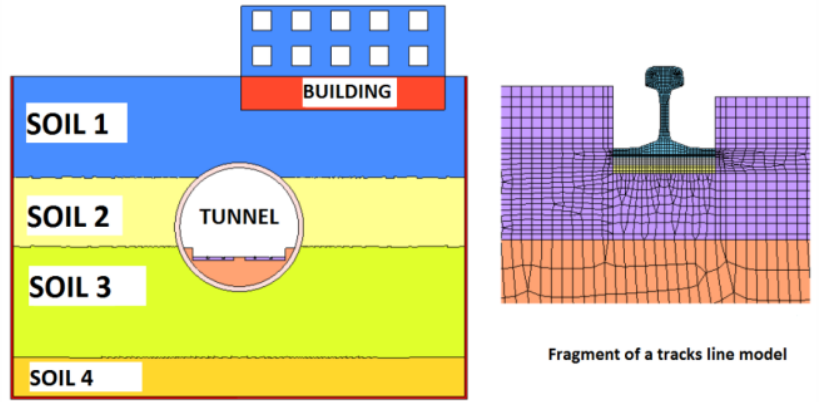

Fragment of a tracks line model

Fig. 10. Sample numerical model with an enlarged fragment of the grid with track finite elements

The next image (fig. 11) shows an exemplary distribution of acceleration for two measurement points on a building located above and below the ground level.

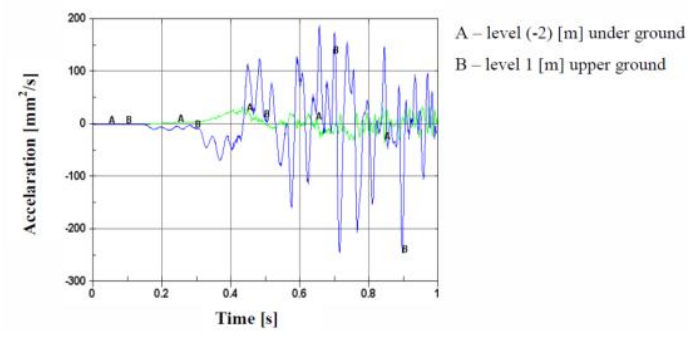

Fig. 11. Exemplary acceleration for the building

\section{Conclusions}

Obtained acceleration results on the ground surface were juxtaposed against the requirements of PN-B-02170:2016-12 standard [5]. The adopted criterion was the amplitude of accelerations at the place of the building foundation (ap), with which it is possible to neglect inertia forces in the building $a_{p} \leq 0.005 \mathrm{~g}=49 \mathrm{~mm} / \mathrm{s}^{2}$.

With the results obtained during the numerical computations for the mats at $\mathrm{g}=30 \mathrm{~mm}$, and $\mathrm{g}=50 \mathrm{~mm}$, a strengthening of signal accelerations was observed for both mats, against the model without insulating mats.

For the insulating mat at $\mathrm{g}=50 \mathrm{~mm}$, at a distance of more than $15 \mathrm{~m}$ from the track axis, acceleration $a_{p}$ is below the maximum value of $49 \mathrm{~mm} / \mathrm{s}^{2}$, and thus it can be neglected in analyses of the vibration effect on buildings.

Based on the analysis conducted, it should be noted that this type of mat, in the form of a continuous liner under the concrete slab will not positively affect the limitation of dynamic effects exerted by rail vehicles, and can even worsen the vibration-insulation effect. The application and this type of slabs in a dispersed form will not satisfy second condition associated with vibroinsulation, as quoted in the literature.

\section{Bibliography}

1. Bednarz J., Targosz J.: Experimental analysis of the propagation of vibrations in the ground caused by the passing rail vehicles [in Polish:Eksperymentalna analiza rozchodzenia się drgań w gruncie wywołanych przejazdem pojazdów szynowych], Logistyka, nr 6, str. 153-160, 2011.

2. Bojko T., Targosz J., Uhl T.: Computer-aided design of vibration isolation systems [in Polish:Komputerowe wspomaganie projektowania układów wibroizolacji], Mechanika, T. 15, Z. 2, 1996.

3. Fialaa P., Degrandeb G., Augusztinovicza F.: Numerical modelling of ground-borne noise and vibration in buildings due to surface rail traffic, Journal of Sound and Vibration, v. 301, 2007.

4. LS-DYNA KEYWORD USER'S MANUAL, 2012

5. Polish standard PN-B-02170:2016-12 - Assessment of the harmfulness of vibrations transmitted by the ground to buildings [in Polish: Polska norma PN-B-02170:2016-12 - Ocena szkodliwości drgań przekazywanych przez podłoże na budynki],

6. Stuit G.: Modelling of soil vibrations from railway tunnels, Journal of Sound and Vibration, v. 267, str. 605-619, 2003.

7. Targosz J.: Analysis of physico-mechanical properties of elastomeric structures minimizing the dynamic impact of the railway track on the environment [in Polish:Analiza i badania właściwości fizykomechanicznych ustrojów elastomerowych, minimalizujacych dynamiczne oddziaływania podtorza kolejowego na otoczenie], TTS - Technika Transportu Szynowego, nr 5-6, str.87-91,2008.

8. Targosz J.: Possibilities of limiting the influence of soil vibrations on engineering structures [in Polish:Możliwości ograniczenia wpływu drgań gruntu na konstrukcje inżynierskie], TTS - Technika Transportu Szynowego, nr 10, str. 3203-3212, 2013. 
9. Targosz J.: Vibroisolation systems for rail and car transport [in Polish:Układy wibroizolacji w transporcie szynowym i samochodowym] , Uczelniane Wydawnictwa Naukowo-Dydaktyczne AGH, Kraków, 2007.

\section{Badania symulacyjne dynamiki wibroizolowanych linii kolejo- wych z układem wibroizolacyjnym na bazie elementów elasto- merowych}

Problem rozchodzenia się fal drganiowych powodowanych ruchem pojazdów szynowych w gruncie jest niezwykle istotny z punktu widzenia ochrony środowiska przed negatywnymi skutkami oddziaływaniami dynamicznych powodowanych przez transport szynowy. W związku z tym istnieje konieczność opracowania nowych metod analizy zjawisk dynamicznych związanych z ruchem pojazdów szynowych. Jedną z metod, którą można wykorzystać do oceny oddziaływań dynamicznych jest modelowanie z wykorzystaniem elementów skończonych. W artykule przedstawiono analizę dynamiczna modelu konstrukcji torowiska oraz wpływu zastosowania jego systemu wibroizolacji na poziom amplitudy drgań gruntu zwiazanej z propagacja fal drganiowych od torowiska. Zastosowanie metody elementów skończonych pozwala na analizę zachowania się konstrukcji inżynierskich w zmiennych warunkach eksploatacyjnych zależnych przede wszystkim od prędkości ruchu pojazdów po torowisku. Analiza taka obejmuje użycie szeregu wartości fizycznych, które mogą służyć do oceny wpływu drgań na dowolny obiekt inżynierski. Do takich wielkości możemy zaliczyć przede wszystkim przyspieszenia $w$ dowolnym punkcie pomiarowym na przekroju pomiarowym od torowiska do konstrukcji inżynierskiej np. budynku mieszkalnego czy przemysłowego jak również przemieszczenia lub naprężenia, które są zależne od prędkości pojazdu szynowego. Porównanie tych wartości z ogólnie dostępnymi kryteriami oraz standardami pozwala na etapie projektowania konstrukcji inżynierskiej na odpowiednie modyfikacje konstrukcji podtorzy celem ograniczenia wartości amplitudy drgań przekazywanych do środowiska. Modyfikacje te polegają głównie na zastosowaniu odpowiedniego układu wibroizolacji w postaci np. płyt lub mat układanych w warstwie torowiska lub podkładek podszynowych. Poprawne wykonanie symulacji wymaga dokładnego przygotowania modelu numerycznego jak i szeregu danych wejściowych. Dane wejściowe dotycza przede wszystkim dokładnych danych materiałowych dotyczących zarówno konstrukcji inżynierskich (mosty, wiadukty, tunele), parametrów taboru jak i gruntu. Takie dane pozwalaja przygotować widmo sił obciążających modelowany odcinek torowiska. Takie podejście do procesu projektowania jest szczególnie istotne ze względu na brak możliwości modyfikacji wybudowanego torowiska po zakończeniu prac budowlanych.

Słowa kluczowe: badania symulacyjne, wibroizolacja, analiza drgań

Autorzy:

dr inż. Jarosław Bednarz AGH Akademia Górniczo-Hutnicza im. Stanisława Staszica, Katedra Robotyki i Mechatroniki, al. Mickiewicza 30, 30-059 Kraków, e-mail: bednarz@agh.edu.pl

dr hab. inż. Jan Targosz, prof. AGH - AGH Akademia Górniczo-Hutnicza im. Stanisława Staszica, Katedra Robotyki i Mechatroniki, al. Mickiewicza 30, 30-059 Kraków, e-mail: jantargosz@interia.pl 